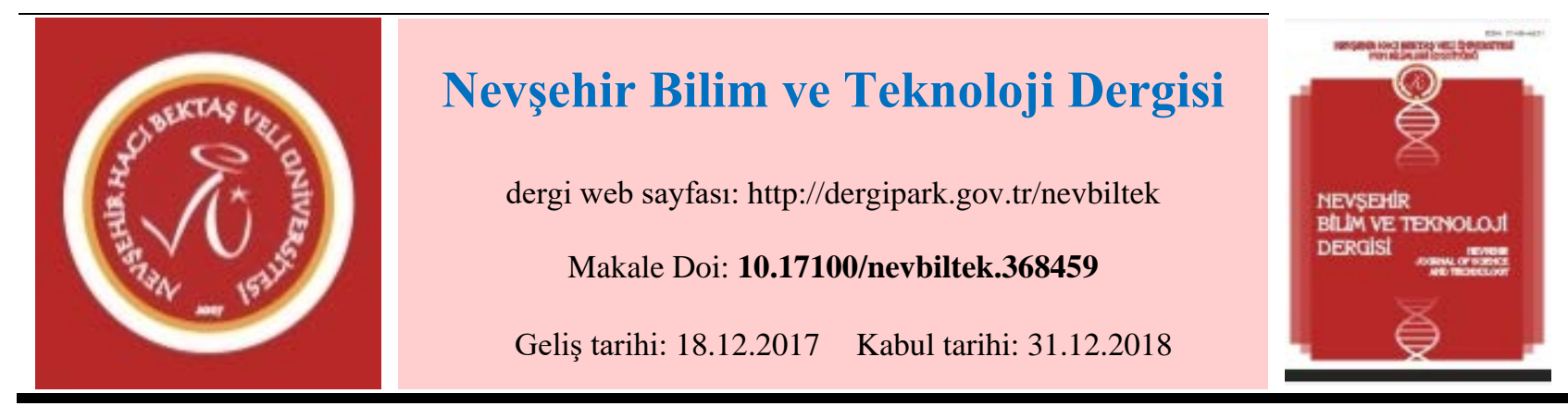

\title{
Effect of Particle Size of Calcium Carbonate on the Short-Term Tensile Creep Properties of Polypropylene Block Copolymer (PPB) ${ }^{1}$
}

\author{
Bülent AYDEMIR ${ }^{1}$, Şenol ŞAHIN ${ }^{2}$, Tülin ŞAHIN ${ }^{2}$ \\ ${ }^{1}$ TUBITAK National Metrology Institute (TUBITAK UME), Force Laboratory, Gebze/Kocaeli \\ ORCID: 0000-0001-6848-2681 \\ ${ }^{2}$ Kocaeli University, Engineering Faculty, Mechanical Engineering Department, Kocaeli
}

ORCID: 0000-0002-7823-2245

ORCID: 0000-0001-7676-2093

\begin{abstract}
Polypropylene block copolymer (PPB) composite materials consist of polypropylene and micro particle mineral filled materials that is calcium carbonate (CC). The samples to be used in the tests were formed by adding calcium carbonate (CC) mineral in three different particle sizes. The different commercial CC minerals average particle sizes are $1.65 \mu \mathrm{m}, 2.15 \mu \mathrm{m}, 5 \mu \mathrm{m}$. The PPB composite materials are prepared at constant quantities of CC with content of 17.5 percentage of the volume ratio (or 38.89\% in weight). In this study, the short time tensile creep behavior of 17,5 vol. \% different particle sizes CC filled PPB materials were investigated for different stress levels. Stress levels were selected from the stress below its yield strength. The stress levels are at $8 \mathrm{MPa}, 16 \mathrm{MPa}$. As a result, it was found that the creep elongation or strain drop $(\Delta \varepsilon)$ values decrease in the CC filled PPB materials according to the unfilled PPB material. In addition, it has been found that the absorbed energy levels reduce as the particle size increases.
\end{abstract}

Keywords: Creep, Polypropylene block copolymer (PPB), Particle size, Calcium carbonate (CC)

\section{Polipropilen Kopolimerinde (PPB) Kalsiyum Karbonat Tane Boyutunun Kısa Süreli Çekme Sürünme Özellikleri Üzerine Etkisi}

Öz

Polipropilen blok kopolimer (PPB) kompozit malzemeler, polipropilen ve mikro tane boyutlu mineral dolgulu malzemelerinden, yani kalsiyum karbonattan (CC) oluşur. Testlerde kullanılacak numuneler, üç farklı tane boyutunda kalsiyum karbonat (CC) mineralinin eklenmesiyle oluşturulmuştur. Farklı ticari CC minerallerinin ortalama tane boyutları 1.65 um, 2.15 um, 5 um'dir. PPB kompozit malzemeler, hacim oranının \% 17.5 'i (veya ağırlıkça \% 38.89) içeriğinde sabit miktarda CC ile hazırlandı. Bu çalışmada, hacimce \%17,5 olan ve farklı boyutlarda CC katkılı PPB kompozit malzemelerin kısa süreli çekme tip sürünme özellikleri farklı gerilme seviyeleri için incelenmiştir. Gerilme seviyeleri, akma dayanımının altındaki gerilmelerden seçilmiştir. Gerilme seviyeleri $8 \mathrm{MPa}$ ve $16 \mathrm{MPa}$ 'dır. Sonuç olarak, katkısız PPB malzemeye göre CC katkılı PPB malzemelerde, sürünme uzaması veya uzama düşüşü $(\Delta \varepsilon)$ değerleri azaldığı tespit edilmiştir. Ayrıca, tane büyüklüğü arttıkça depolanan enerji seviyelerinin azaldığı da bulunmuştur.

Anahtar Kelimeler: Sürünme, Polipropilen blok kopolimer (PPB), Tane boyutu, Kalsiyum karbonat (CC)

\footnotetext{
${ }^{1}$ Sorumlu yazar e-mail: bulent.aydemir@tubitak.gov.tr Bu makale IMSTEC 2017 sunulmuştur.
} 


\section{Introduction}

Development of rigid polypropylene (PP) composites highly filled with CC provides a great commercial significance because of increased performance of polymeric material, cost, and improved properties of materials. Mineral fillers play an important role as particle reinforcing agents in thermoplastics industry, especially talc and calcium carbonate [1]. Modification of filler not only contributes to reinforcement but is also very useful in increasing the interaction of particles to impart rheological properties, prevent sedimentation, aid dispersion, or prevent agglomeration [2-4].

The tensile creep behavior or/and tensile creep rupture [5] of polypropylene block copolymer (PPB) and its micro particle mineral filled PPB composite materials is still one of the least understood failure mechanisms and is also still unclear. The mechanical properties of filled polymers have been widely studied [6-9]. In addition to this work, the design engineer of plastic component parts are needed more than just short-term stress-strain data for anticipating long term deformation behavior. For example, the useful service lifetime of the molded part is curtailed by onset of excessive creep deformation, leading to ultimate creep rupture. Consequently, there have been significant efforts by researchers to correlate creep strain with stress-temperature-time parameters that suit end-use constraints imposed on material design.

The short time creep and relaxation behavior of the polymers is quite important for lifetime prediction of the components $[10,11]$. The aim of this study was examined the short time creep behavior of 17,5 vol. \% different particle sizes CC filled PPB materials for different stress levels under uniaxial tensile loading.

\section{Material and Method}

\subsection{Material}

In this study, the PPB raw material, which has a commercial name of BorECOTM BEC5015 (Borealis A/S), with a density of $900 \mathrm{~kg} / \mathrm{m}^{3}$ and $0.3 \mathrm{~g} / 10 \mathrm{~min}\left(230^{\circ} \mathrm{C} / 2.16 \mathrm{~kg}\right)$ melt flow rate (MFR) has been used. The other mechanical properties of PPB from the manufacturer are given as $1500 \mathrm{MPa}$ tensile modulus, $30 \mathrm{MPa}$ tensile stress at yield and $10 \%$ tensile yield elongation, which are measured according to ISO 527-2 [12] on standard injection moulded specimens.

As fillers, three calcium carbonate (CC) filler material with density of $2700 \mathrm{~kg} / \mathrm{m}^{3}$ and $1.65 \mu \mathrm{m}$ (CC1), 2.15 $\mu \mathrm{m}$ (CC2) and $5.00 \mu \mathrm{m}$ (CC3) average particle sizes, which the commercial names are in same order Mikrocarb-1, Mikrocarb-2X and Mikrocarb-5 (Mikro Mineral Industrial Minerals Industry), were used. The white micronized CC minerals manufacturer information's were given in Table 1.

Table 1. Manufacturer information's of CC minerals

\begin{tabular}{ccccc}
\multicolumn{4}{c}{ Table 1. Manufacturer information's of CC minerals } \\
\hline Particle Size & Unit & \multicolumn{3}{c}{ Typical Value } \\
& & CC1 & CC2 & CC5 \\
\hline Average dia., d(0.5) & $\mu \mathrm{m}$ & 1.65 & 2.15 & 5.00 \\
Top Cut, d(0.97) & $\mu \mathrm{m}$ & 7.50 & 11.60 & 28.00 \\
Below 2 $\mathbf{~ m ~ [ m i n . ] ~}$ & $\%$ & 57 & 48 & 30 \\
Sieve 45 $\boldsymbol{\mu m}$ [max.] & $\%$ & 0.01 & 0.01 & 0.1 \\
\hline
\end{tabular}

The composite raw materials were manufactured with physical modification method at constant quantities of CC with content of 17.5 percentage of the volume ratio (or $38.89 \%$ in weight). For the PPB composite raw materials production, a twin-screw extruder (Coperion Werner and Pleiderer ZSK 25 P8.2 E WLE) with screw-ratio (L/D) of 45 and screw length (L) of $1125 \mathrm{~mm}$ was used. The production of the composite raw materials has been performed with fixed parameters.

The multipurpose test specimens of pure PPB and CC filled PPB composite materials were injection moulded using an injection moulding machine (arburg allrounder $370 \mathrm{CMD}$ ) with $25 \mathrm{~mm}$ of screw diameter (D) and screw ratio (L/D) of 20. The injection moulding process has been carried out according to ISO 294-1 [13] and with the fixed parameters under the conditions of 1450 bar of injection pressure, 650 bar of hold pressure, $60 \mathrm{~s}$ of hold time, $225^{\circ} \mathrm{C} /$ $220^{\circ} \mathrm{C} / 220^{\circ} \mathrm{C} / 215^{\circ} \mathrm{C}$ of zones temperatures from the feeding zone to the nozzle zone, $225^{\circ} \mathrm{C}$ of melt temperature and $30^{\circ} \mathrm{C}$ of water temperature for mould cooling. The multipurpose test specimens Type-1A according to ISO 3167 [14] are directly injected moulded, on the dimensions of $216 \mathrm{~mm}$ x $10 \mathrm{~mm}$ x $4 \mathrm{~mm}$ (Fig. 1) in a two cavity Type-A ISO tensile mould with T-runner according to ISO 294-1. 


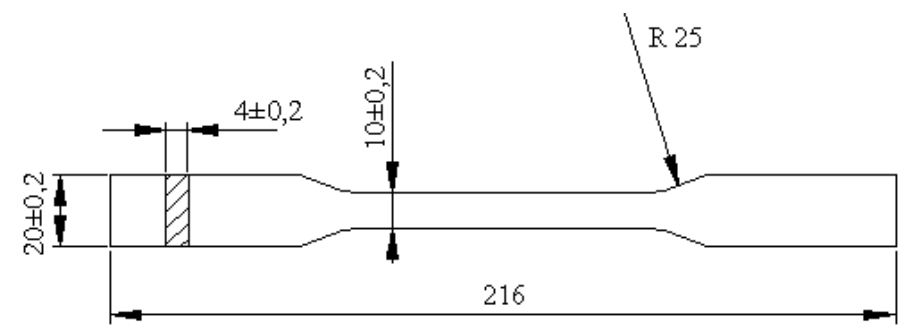

Fig. 1. The dimensions of the samples (mm)

\subsection{Method}

The experiments were conducted with a Zwick Z250 tensile machine at the National Metrology Institute (UME) in TUBITAK. The standard test method for creep characterization is ASTM D2991 [15].

The specimen was gripped by jaws and applied to preload. Then, extensometer was automatically attached on it and remained on throughout the entire test. Gage length of extensometer was applied $50 \mathrm{~mm}$. Each group was tested with 3 samples. All samples were tested under identical testing protocols. To investigate the behavior of pure PPB and $\mathrm{PPB} / \mathrm{CC}$ composite materials, the following experiments were performed: Firstly, uniaxial loading and unloading at E-3 $1 / \mathrm{s}$ strain rates. Secondly, relaxation at different stress levels, $8 \mathrm{MPa}$ and $16 \mathrm{MPa}$ for $600 \mathrm{~s}$.

The uniaxial tensile test properties of pure PPB and PPB/CC composite materials were given in Table 2.

\begin{tabular}{|c|c|c|c|c|c|}
\hline \multirow{3}{*}{ Sample Name } & \multirow{3}{*}{$\begin{array}{c}\text { Young's Module } \\
\text { [MPa ] }\end{array}$} & \multicolumn{2}{|c|}{ Stress at } & \multicolumn{2}{|c|}{ Strain at } \\
\hline & & Yield & Break & Yield & Break \\
\hline & & \multicolumn{2}{|c|}{ [MPa] } & \multicolumn{2}{|c|}{$[\mathrm{mm} / \mathbf{m m}]$} \\
\hline Pure PPB & 1708,41 & 29,34 & 21,78 & 0,071 & 2,860 \\
\hline PPB/CC1 & 2842,83 & 21,79 & 18,54 & 0,030 & 2,375 \\
\hline PPB/CC2 & 3084,42 & 22,16 & 18,88 & 0,033 & 1,210 \\
\hline PPB/CC5 & 3355,10 & 21,38 & 18,56 & 0,038 & 3,256 \\
\hline
\end{tabular}

\section{Results and Discussion}

For a short time creep description of material behavior of different particle size CC in PPB polymer composites, constant force and total strain were performed at different stress levels. $8 \mathrm{MPa}$ stress level was chosen because it is below the yield point stress. $16 \mathrm{MPa}$ stress level point is approximately mean of yield stress. As seen in Fig. 2, increasing strain level increases percentage of strain level.

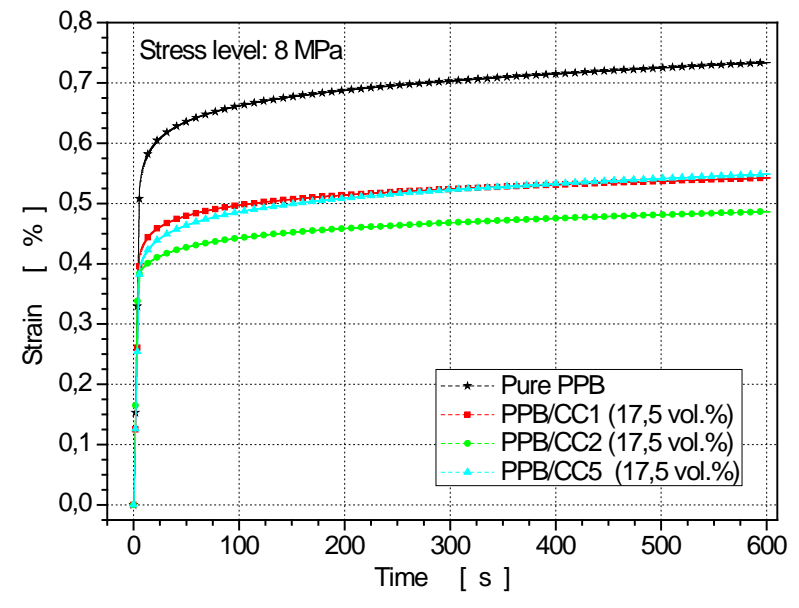

(a)

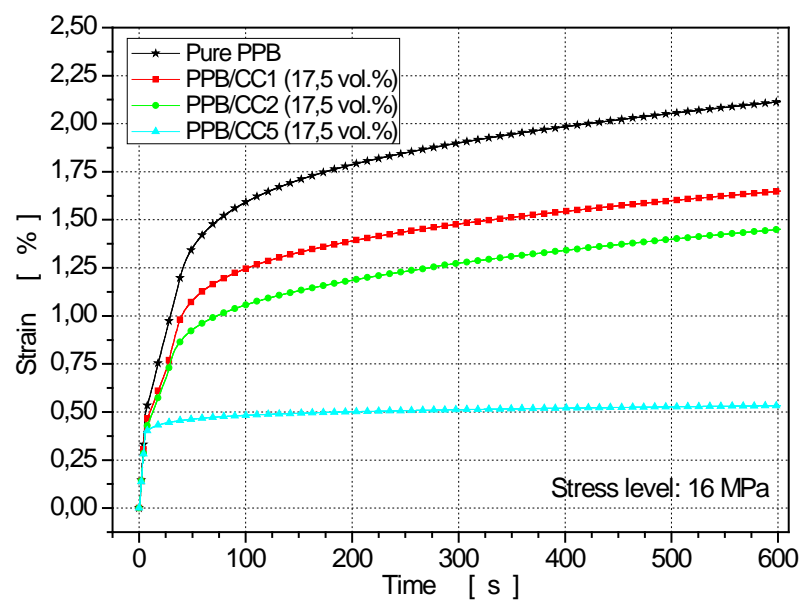

(b)

Fig. 2. Strain-Time Curves of PPB at $650 \mathrm{psi}, 23^{\circ} \mathrm{C}$ Creep Strain versus Time. a) $8 \mathrm{MPa}$, b) $16 \mathrm{MPa}$

According to the literature, Aydemir 2012, Dusunceli et all 2007 and Dusunceli et all 2008, Sahin et all 2017 $[10,11,16,17]$ studies were found similar results for PP and PE material. The primary creep at the stress values of $8 \mathrm{MPa}$ and $16 \mathrm{MPa}$ were appeared. The material showed resistance to deformation. Stress-strain curves for the tests were 
depicted in Fig 3. The behavior of the stress-strain curves in the creep results of the materials of all particle sizes (1.65 $\mu \mathrm{m}, 2.15 \mu \mathrm{m}, 5 \mu \mathrm{m}$ ) were shown the same at both stress levels. As the stress value increased, the maximum strain values increased. Especially, irregular creep curves were observed with the results of $5 \mu \mathrm{m}$ particle size CC filled PPB material samples.

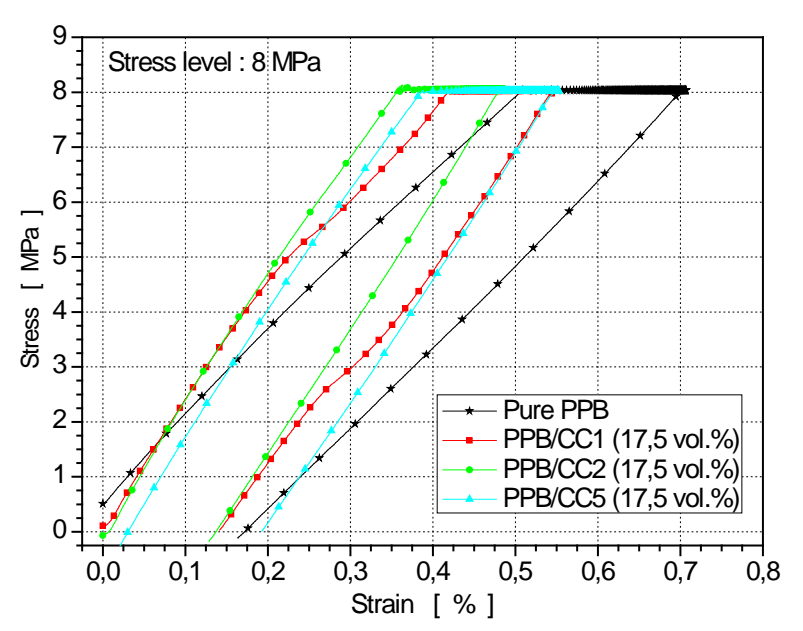

(a)

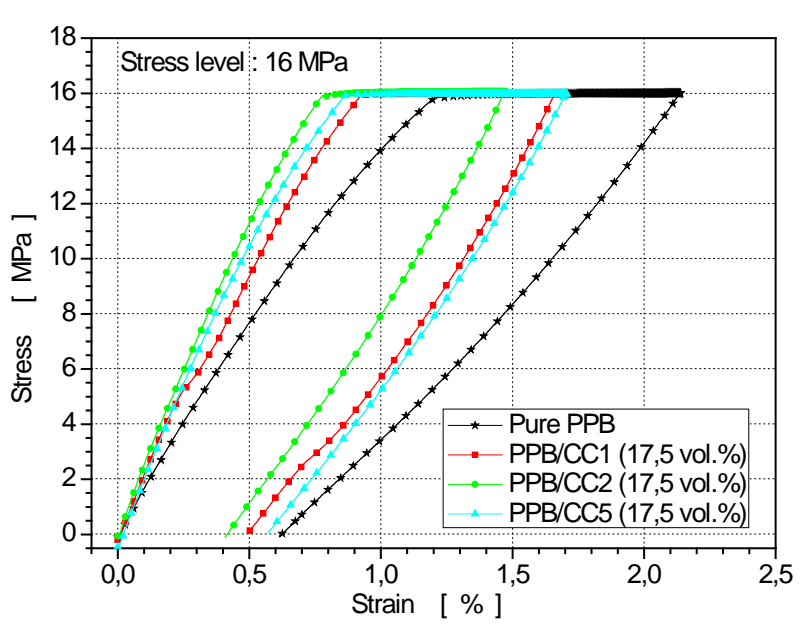

(b)

Fig. 3. Tensile-Creep Curve of PPB for different stress level and particle size of CC (at 600s, 23ㄷ). a) 8MPa b) $16 \mathrm{MPa}$

Generally, the absorbed energy (W) is defined as the area under the curve of stress-strain. Fig. 4 shows the absorbed energy (W) of pure PPB and PPB/CC composites for 8 MPa and 16 MPa stress levels. The absorbed energy increased with increasing stress level. Adding, the absorbed energy level decreased as the particle sizes increase. At 8 MPa stress level, absorbed energy of pure PPB was reduced about $37 \%$ according to PPB/CC5 sample. The change of absorbed energy level for $16 \mathrm{MPa}$ stress level was about $27 \%$. The decrease in absorbed energy according to the stress level were also observed in the literature studies [10-11].

As seen in Fig.5, the increased stress level increased the maximum strain values. As stress levels changed 8 MPa to $16 \mathrm{MPa}$, the strain value for pure PPB sample increased about 2,9 times, and the strain value for PPB/CC5 was about 3,3 times. Different particle size of calcium carbonate into PPB did not have a significant effect on creep elongation values or maximum strain value. Adding, the maximum strain values decreases in the PPB materials according to the pure PPB material.

The percentage of strain drop $(\Delta \varepsilon)$ or creep elongation is shown in Fig. 6 . When the stress level is doubled, the average strain drop increased as the particle sizes increase. In pure material this value is 4.8 times while it is 5.5 times in the largest particle size.

Tensile break strength decreased about $14 \%$ in pure PPB material according to the calcium carbonate filled PPB material (Table 2). In contrast, the absorbed energy value increased by about $30 \%$ for two different stress levels. Adding, the creep elongation or strain drop $(\Delta \varepsilon)$ values decreased about $19 \%$ in the calcium carbonate filled PPB materials according to the unfilled PPB material. As a result, the creep elongation of the calcium carbonate filled PPB materials, at room temperature under a constant load, will be $19 \%$ less. It shows that the calcium carbonate additive can be used to improve creep elongation for PP materials. 
Nevşehir Bilim ve Teknoloji Dergisi (2018), 7(2) 206-213

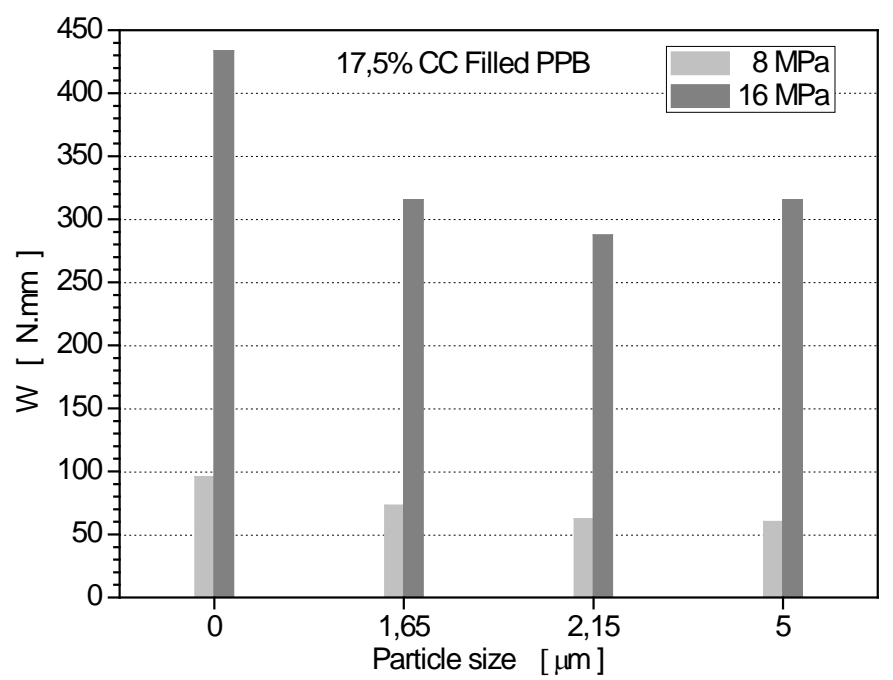

Fig. 4. Absorbed energy (W) of pure PPB and PPB/CC composites at $8 \mathrm{MPa}, 16 \mathrm{MPa}$ stress levels

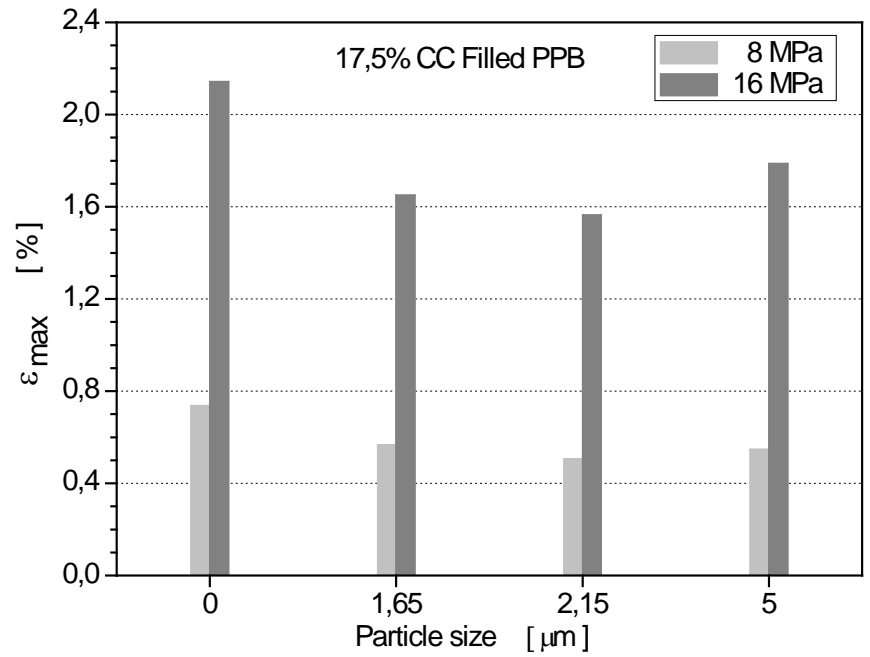

Fig. 5. The percentage of maximum strain values $\left(\varepsilon_{\max }\right)$ of pure PPB and PPB/CC composites at 8 MPa, 16 MPa stress levels

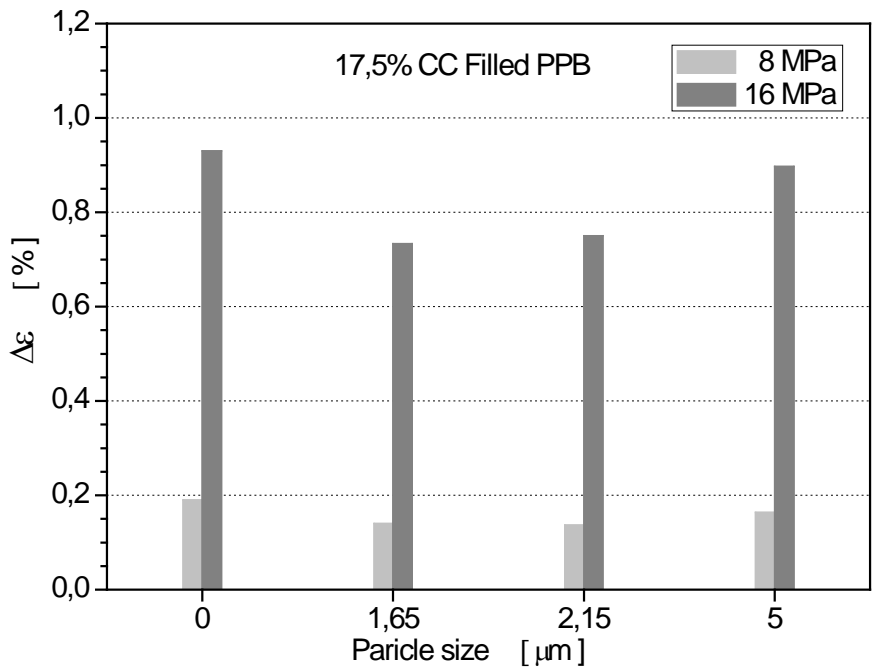

Fig. 6. The percentage of strain drop $(\Delta \varepsilon)$ of pure $\mathrm{PPB}$ and $\mathrm{PPB} / \mathrm{CC}$ composites at $8 \mathrm{MPa}, 16 \mathrm{MPa}$ stress levels

\section{Conclusions}

In this study, the short time tensile creep behavior of PPB and 17,5 vol. \% different sizes CC particles filled PPB material were investigated. The conclusions are summarized as follows.

- As stress levels changed $8 \mathrm{MPa}$ to $16 \mathrm{MPa}$, the maximum strain values increased approximately 3,1 times. The maximum strain values decreases in the PPB materials according to the unfilled PP material. 
Nevşehir Bilim ve Teknoloji Dergisi (2018), 7(2) 206-213

- Added different particle size of calcium carbonate into PPB did not have a significant effect on creep elongation values and absorbed energy values.

- The absorbed energy value with calcium carbonate particles filled into PPB material reduced about $32 \%$. In addition, it has been found that the absorbed energy level decreases as the particle size increases.

- The percentage of strain drop $(\Delta \varepsilon)$ increased approximately 5,2 times, as increasing the stress level.

- The creep elongation or strain drop $(\Delta \varepsilon)$ values decreased about $19 \%$ in the calcium carbonate filled PPB materials according to the unfilled PPB material.

\section{References}

[1] Barnes, H. A.; Hutton, J. F.; Walters, K. An Introduction to Rheology; Elsevier Science: Amsterdam, 1989.

[2] Zuiderduin, W. C. J.; Westzaan, C.; Huetink, J.; Gaymans, R. J. Polymer, 44, 261, 2003.

[3] Campbell, Les E. Characterization of long-term creep-fatigue behavior for glass fiber-reinforced polypropylene. Pp 532 , Edited by Harutun G. Karian, Marcel Dekker, USA

[4] Jansen, J.Plastics Engineering, July August, 2015.

[5] Pukanszky, B. Particulate filled polypropylene: structure and properties.. Polypropylene Structure, blends and composites, Chapman\&hall, ISBN: 0412614308, vol 3, Part 1 edited by J. Karger-Kocsis, 1995.

[6] Harutun, G. Karian, Handbook of Polypropylene and Polypropylene Composite, second edition, Marcel Dekker USA,pp 469, 2003.

[7] H.P. Schlumpf, Plastics Additives Handbook, Stabilizers, Processing Aids, Plasticizers, Fillers, Reinforcements, Colorants for Thermoplastics. Edited by R.Gachter and R.Müller pp534, Hanser publishers, 3rd edition, ISBN:3446156801,1990.

[8] Meng Deng, Jack Zhou, J Mater Sci: Mater Med, 17: 365-369, 2006.

[9] Akhtar, S. Khan, Oscar Lopez-Pamies, International Journal of Plasticity 18, 1359-1372, 2002.

[10] Aydemır, B, Elastomere und Kunststoffe (Elastomers and Plastıcs), Sep (2012), pp 35-38.

[11] Dusunceli, N., Colak, O.U.; Mech Time-Depend Mater, 2007; 10; 4; 331-345

[12] EN ISO 527-2, Plastics - Determination of tensile properties - Part 2: Test conditions for moulding and extrusion plastics, 1996

[13] ISO 294-1. Plastics-Injection Moulding of Test Specimens of Thermoplastics Materials (Part1), 1996.

[14] ISO 3167. Plastics-Multipurpose Test Specimens, 2014.

[15] ASTM D2991, Recommended Practice for Testing Stress-Relaxation of Plastics, 1984

[16] Dusunceli, N., Colak, O.U.; Inter. J Plasticity; 2008; 24; 1224-1242

[17] Şahin, Ş, Aydemir, B, Şahin, T, 7th International Advances in Applied Physics And Materials Science Congress \& Exhibition ,93, 2017 


\section{Uzun Özet}

\section{Giriș}

Kalsiyum karbonat (CC) ile yüksek oranda takviye edilmiş polipropilen (PP) kompozitlerin geliştirilmesi, polimerik malzemenin performansı, maliyeti ve malzemelerin gelişmiş özellikleri nedeniyle büyük bir ticari öneme sahiptir. Mineral dolgu maddeleri, termoplastik endüstrisinde, özellikle talk ve kalsiyum karbonat olmak üzere partikül takviye edici maddeler olarak önemli bir rol oynamaktadır. Dolgunun modifikasyonu sadece donatıya katkıda bulunmakla kalmaz, aynı zamanda reolojik özellikler kazandırmak, çökeltmeyi önlemek, dağılmaya yardımcı olmak veya topaklanmayı önlemek için parçacıkların etkileşiminin arttırılmasında da çok faydalıdır.

Çekme sürünme davranışı veya polipropilen blok kopolimerinin (PPB) ve mikro taneli mineral dolgulu PPB kompozit malzemelerinin gerilme sürünme kırılması, hala en az anlaşılan hasar mekanizmalarından biridir ve hala belirsizdir. Takviyeli polimerlerin mekanik özellikleri geniş ölçüde incelenmiştir. Bu çalışmaya ek olarak, plastik bileşen parçaların tasarım mühendisine, uzun vadeli deformasyon davranışını öngörebilmesi için kısa vadeli gerilmeuzama verilerinden daha fazlasına ihtiyaç duyulmaktadır. Örneğin, kalıplanmış parçanın faydalı servis ömrü, aşırı sürünme deformasyonunun başlamasıly kesilerek, sürünmenin kopmasına neden olur. Sonuç olarak, araştırmacılar tarafından sürünme davranışı için, malzeme tasarımına uygulanan son kullanım kısıtlamalarına uyan gerilme-sıcaklıkzaman parametreleri ile ilişkilendirmek için önemli çabalar sarf edilmiştir.

Polimerlerin kısa süreli sürünme ve gevşeme davranışı, bileşenlerin ömür tahmini için oldukça önemlidir. $\mathrm{Bu}$ çalışmanın amacı 17,5 hacim oranlı farklı tane büyüklüğündeki CC ile takviye edilmiş PPB malzemelerinin tek eksenli çekme yükü altında farklı gerilme seviyeleri için kısa süreli sürünme davranışı incelenmesidir.

\section{Yöntem}

Saf PP ile kalsiyum karbonat (CC) takviyeli PPB kompozit malzemelerin çok amaçlı test örnekleri enjeksiyon presleme ile hazırlanmıştır. Enjeksiyon kalıplama işlemi ISO 294-1'e göre yapılııştır. ISO 3167'ye göre Tip-1A çok amaçlı test numuneleri doğrudan enjeksiyonla kalıplandılar.

ASTM D2991 de tarif edilen standard test yöntemine göre sürünme karakterizasyonları yapıldı. Deneylerde TÜBİTAK Ulusal Metroloji Enstitüsü (UME) 'deki Zwick Z250 çekme makinesi kullanıldı. Makinanın kuvvet sensörü ISO 7500-1 standardına göre ve makinanin ekstansometresi ise ISO 9513 standardına göre kalibre edilmiştir. Numuneler makina çenelerine tutturuldu ve düşük bir ön yükleme kuvveti uygulandı. Daha sonra, ekstansometre otomatik olarak numune üzerine takıldı ve testin tamamında uzama okudu. Ekstensometre ölçüm uzunluğu $50 \mathrm{~mm}$ olarak alındı. Her grup için 3 adet numune test edildi. Tüm numuneler aynı test şartları altında test edildi.

$\mathrm{Bu}$ çalışmada, \% 17,5 hacim oranlı farklı tane büyüklüklü kalsiyum karbonat (CC) ile oluşturulmuş polipropilen blok kopolimer (PPB) kompozit malzemelerin kısa süreli çekme sürünme davranışı, incelenmiştir. Saf PP ve PPB / CC kompozit malzemelerin davranışını araştırmak için deneyler yapıldı: İlk önce, 1E-3 1/s gerilme oranlarında tek eksenli çekme yükleme ve boşaltma testi, ikinci olarak, $600 \mathrm{~s}$ süre için farklı gerilme seviyelerinde (8 MPa ve 16 MPa da) gevşeme testleridir. Ayrıca, ilave orarak, Saf polipropilen (PP) ve PPB / CC kompozit malzemelerin tek eksenli çekme testi özellikleri de incelenmiştir.

\section{Bulgular}

Farklı tane büyüklüklü kalsiyum karbonat (CC) takviyeli polipropilen blok kopolimer (PPB) kompozit malzemelerin kısa süreli sürünme davranışının açıklaması, farklı gerilme seviyelerindeki kuvvetin sabit tutulması ile gerçekleştirildi. Malzemenin akma gerilmesinin altında bir değer olarak $8 \mathrm{MPa}$ gerilme seviyesi seçilmiştir. $16 \mathrm{MPa}$ gerilme seviyesi ise yaklaşık olarak mazemelerin akma gerilmesinde bir değerdir. Bilindiği üzere, gerilme seviyesindeki artı̧̧ uzama seviyesinin yüzdesini de arttıracaktır.

Literatüre göre, Aydemir 2012, Dusunceli 2007, Dusunceli 2008 ve Şahin 2017'nin yaptığ çalışmalarda, polipropilen (PP) ve polietilen (PE) malzemeleri için yapılan sürünme deneyi çalışmalarında benzer sonuçlar bulmuştur. $8 \mathrm{MPa}$ ve $16 \mathrm{MPa}$ gerilme değerlerinde primer sürünme gözlenmiş ve malzemeler deformasyona direnç göstermiştir. Test sonuçları olarak, bu çalışmada, malzemelerin gerilme-uzama eğrileri verildi. Gerilme-uzama eğrilerinin tüm tane boyutlarındaki malzemelerin $(1.65 \mu \mathrm{m}, 2.15 \mu \mathrm{m}, 5 \mu \mathrm{m})$ sonuçlarındaki sürünme davranışı incelendiğinde her iki gerilme seviyesinde de aynı şekilde elde edilmiştir. Gerilme değeri artıkça, maksimum uzama değerleri de artmıştır. Özellikle, $5 \mu \mathrm{m}$ tane büyüklügünndeki kalsiyum Karbonat (CC) ile takviye edilmiş olan polipropilen blok kopolimer (PPB) kompozit malzeme numunelerinin sonuçlarında düzensiz sürünme eğrileri gözlemlenmiştir. 
Genellikle, absorblanan enerji (W), gerilme-uzama eğrisinin altındaki alan olarak tanımlanır. Absorblanan enerji artan gerilme seviyesi ile arttığı görülmüştür. İlave olarak, absorblanan enerji seviyesi tane büyüklüğü arttıkça azaldı gözlemlenmiştir. $8 \mathrm{MPa}$ gerilme seviyesinde, saf polipropilen (PP)'nin absorbe edilen enerjisi, PPB / CC5 örneğine göre yaklaşık \% 37 azalmıştır. $16 \mathrm{MPa}$ gerilme seviyesi için absorbe edilen enerji seviyesindeki değişim ise yaklaşı \% 27 olarak belirlenmiştir. Benzer şekilde, literatürdeki çalışmalarda da absorbe edilen enerjinin gerilme seviyesindeki artış ile azaldığı belirtilmiştir.

Bilindiği gibi, artan gerilme seviyesi maksimum uzama değerlerini arttırmaktadır. Gerilme seviyeleri 8 MPa'dan 16 MPa'ya değiştiğinde, maksimum uzama değeri, saf polipropilen (PP) numunesi için yaklaşık 2,9 kat arttı ve PPB / CC5 için ise yaklaşık 3,3 kat arttığ gözlemlenmiştir. Polipropilen blok kopolimer (PPB) içerisindeki farklı kalsiyum karbonat tane boyutunun sürünme uzama değerleri veya maksimum uzama değerleri üzerinde önemli bir etkisi olmamıştır. İlave olarak, polipropilen blok kopolimer (PPB) kompozit malzemelerinde maksimum uzama değerlerindeki düşüş saf polipropilen (PP) malzemesine göre daha azalır.

Gerilme seviyesi iki katına çıktığında, ortalama uzama değerindeki düşüş tane büyüklüğü arttıkça artmıştır. Saf malzemede bu değer 4.8 kat, en büyük tane büyüklüğünde katkılı polipropilen blok kopolimer (PPB) malzemesi için ise 5.5 katıdır. Çekme kopma mukavemeti, kalsiyum karbonat takviyeli polipropilen blok kopolimer (PPB) kompozit malzemesinde saf polipropilen (PP) malzemesine göre yaklaşık \% 14 azalmıştır. Buna karşılık, absoblanan enerji değeri iki farklı gerilme seviyesi için yaklaşık \% 30 arttığı bulunmuştur. İlave olarak, takviyesiz polipropilen (PP) malzemesine göre kalsiyum karbonat (CC) takviyeli polipropilen blok kopolimer (PPB) kompozit malzemelerinde sürünme uzaması veya gerilme düşüşü $(\Delta \varepsilon)$ değerleri yaklaşık \% 19 azalmıştır. Sonuç olarak, kalsiyum karbonat takviyeli polipropilen blok kopolimer (PPB) kompozit malzemelerinin oda sıcaklığında sabit bir kuvvet altında sürünme uzaması \% 19 daha az olacaktır. Bu değerde, kalsiyum karbonat katkı malzemesinin polipropilen (PP) malzemelerin sürünme uzama davranışlarını geliştirmek için kullanılabileceğini göstermektedir. Sonuç olarak, Kalsiyum karbonat (CC) takviyeli polipropilen blok kopolimer (PPB) kompozit malzemelerinde, takviyesiz polipropilen (PP) malzemesine göre sürünme uzama veya gerilme düşüşü $(\Delta \varepsilon)$ değerlerinin azalttığı tespit edildi. Ayrıca, ilave olarak, absorblanan enerji seviyelerinin tane büyüklüğü arttıkça azaldığı bulunmuştur.

\section{Sonuç ve Tartışma}

Bu çalışmada, 17,5 hacim oranlı farklı tane büyüklüğündeki CC ile takviye edilmiş PPB malzemelerinin tek eksenli çekme yükü altında farklı gerilme seviyeleri için kısa süreli sürünme davranışı incelendi. Sonuçlar aşağıdaki gibi özetlenmiştir. Gerilme seviyeleri $8 \mathrm{MPa}$ 'y $16 \mathrm{MPa}$ ya değiştirdiğinde, maksimum uzama değerleri yaklaşık 3,1 kat arttı. PPB malzemelerinde maksimum uzama değerleri, takviyesiz PP malzemesine göre azalır. PPB içerisine farklı tane boyutlu kalsiyum karbonat eklenmesinin, sürünme uzama değerleri ve absorblanan enerji değerleri üzerinde önemli bir etkisi olmamıştır. PPB malzemesine katılan kalsiyum karbonat taneleri ile absorblanan enerji değeri yaklaşık \% 32 azalmıştır. İlave olarak, tane büyüklüğü arttıkça absorbe edilen enerji seviyesinin düştüğü bulunmuştur. Gerilme seviyesi artarken uzama değerindeki düşüş $(\Delta \varepsilon)$ miktarı yaklaşık 5,2 kat arttı. Sürünme uzaması veya uzama düşüşü $(\Delta \varepsilon)$ değerleri, takviyesiz PP malzemesine göre kalsiyum karbonatla takviyeli PPB malzemelerinde yaklaşık \% 19 oranında azalmıştır. 